\title{
Characterization of the Chemical Components of the Extracted Carduus Pycnocephalus L, and Assessment of Its Potential Novel Antioxidant, Antibacterial, and Anticancer Activities
}

\author{
Luay El Hayyany \\ Mansoura University Faculty of Science \\ El-Sayed El-Halawany \\ Mansoura University Faculty of Science \\ Hoda Soliman \\ Mansoura University Faculty of Science \\ Yasser El-Amier ( $\nabla$ yasran@mans.edu.eg) \\ Mansoura University Faculty of Science https://orcid.org/0000-0001-8920-8278
}

Research Article

Keywords: Carduus pycnocephalus, GC/MS Chromatography, DPPH Antioxidant, Cytotoxic and Antibacterial Activities

Posted Date: November 5th, 2021

DOI: https://doi.org/10.21203/rs.3.rs-1019997/v1

License: (9) (7) This work is licensed under a Creative Commons Attribution 4.0 International License. Read Full License 


\section{Abstract}

Carduus pycnocephalus $\mathrm{L}$, which is related to the Astraceae family, was well-known as a privileged medicinal plant that has innumerable respected biological potency. The current research aims to identify the chemical constitutes of the essential oils of the extracted $C$. pycnocephalus by Gas Chromatography-Mass Spectroscopic analysis (GC-MS) and to assess the biological profiles of the plant and its botanical ingredients as a precise antioxidant, and anticancer, as well as, antimicrobial agents. The extraction process of the medicinal plant by methanol provided a possibility to extract and identify the polar chemical constitutes that have the most effective categories of components. The DPPH antioxidant potency of the botanical ingredients of the plant indicated that the flower extract is the most potent with $\mathrm{IC}_{50}=30.69 \mathrm{mg} / \mathrm{L}$ followed by leaves $\left(I C_{50}=32.78 \mathrm{mg} / \mathrm{L}\right)$, stem $\left(I \mathrm{C}_{50}=41.31 \mathrm{mg} / \mathrm{L}\right)$, and root $\left(\mathrm{IC}_{50}=46.84 \mathrm{mg} / \mathrm{L}\right)$. The antibacterial activities of the root, stem, leaf, and flower extracts of $C$. pycnocephalus exhibited remarkable potency to kill or inhibit the growth of the bacterial species. Leaf, and flower extracts revealed the most potent activities than the antibiotic standards against $E$. coli, S. typhimurium, and B. cereus species with inhibition zones ranged from $20-26 \mathrm{~mm}$. Also, the extracted $C$. pycnocephalus revealed a moderate cytotoxic effect against hepatocellular carcinoma (HepG2) tumor cell line using MTT assay with $\mathrm{IC}_{50}=46.2 \mu \mathrm{g} / \mathrm{mL}$. The experimental interpretations inveterate the potential of $C$. pycnocephalus extract indicated its biological impacts as antioxidant, antibacterial, and moderate cytotoxic agents that provided the ease of using it in cancer therapy.

\section{Introduction}

The Carduus genus is related to Astraceae family, which included roughly 100 species worldwide according to Chaudhary (2000) that are extensively distributed from place to place in the Mediterranean. Only three species of Carduus genus were recorded in the flora of Egypt, $C$. pycnocephalus, $C$. getulus and $C$. argentatus. The latter is a spiny annual herb growing wildly in the coastal desert of Egypt. The stem usually branches and has spiny wings, the plant reaches up to $60 \mathrm{~cm}$ with the taproot, which gives greyish-tomentose on the lower surface, with spinose lobes, and its flowering time extends from March to May (Boulos 1983). Flu, stomach ache, and rheumatism of such human diseases were treated by Carduus genus in Chinese folk medicine (Esmaeili et al. 2005). In addition, the genus of Carduus revealed many biological characteristics, for example, antibacterial, antiviral, anticancer, antispasmodic, anti-inflammatory, and liver tonicity activities (Al-Shammari et al. 2015; Esmaeili et al. 2005; Jordon-Thaden \& Louda 2003; Orhan et al. 2009). Rhinocyllus conicus (Coleoptera: Curculionidae), as a type of Carduus species (Asteraceae) that grown in Argentina, was applied as a control for thistles (de Briano et al. 2013). Many types of research since antiquity and in recent times have focused on the study of Carduus species such as the study of the reproductive system (Olivieri et al. 1983), ecology (Doing et al. 1969), the accumulation of heavy metals in plants growing in contaminated soils (Brunetti et al. 2009), recovery of the colonization of the rootstock of mycorrhizal fungi (Jaunatre et al., 2016), and comparative studies electrophoresis (Olivieri 1985).

The phytochemical analysis of several types of plants related to this Carduus genus indicated the characterization of diverse classes of chemical constitutes such as flavonoids, and Coumarin (Jordon-Thaden \& Louda, 2003), as well as earlier reports, reported the identification of other classes of secondary metabolites such as lignans, alkaloids, sterols, and triterpenes. In this due course, $C$. pycnocephalus was well-known in the literature as an anti-inflammatory, antispasmodic, and hypotensive agent, in which the isolated components 
from the different parts of this plant were characterized by spectroscopic analyses (Al-Shammari et al. 2015). The literature survey in earlier reports has also identified the isolation of many other classes from $C$. pycnocephalus such as essential oils (Esmaeili et al. 2005), sterols, and triterpenes (Gallo \& Sarachine 2009). Al-Shammari et al. (2015), have characterized ten compounds from the aerial parts of this plant that were related to flavonoid class, and anthraquinone, anthraquinone-linked carbohydrate, steroids, and steroids-linked carbohydrate derivatives as subclasses including kaempferol-7-methoxy-3-O- $\alpha$-L-rhamnoside, diosmetin-7-O- $\beta$ D-xylosyl- $\beta$-D-gluco-pyranoside, diosmetin-7-O- $\alpha$-L-arabinosyl- $\beta$-D-gluco-pyranoside, and kaempferol-3-O- $\alpha$-Lrhamnosyl-a-L-rhamnoside along with the structures that were depicted in Figure 1.

Esmaeili et al. (2005), have reported the analysis of the essential oils isolated from C. pycnocephalus that were grown in Iran by Gas Chromatography-Mass Spectroscopic analysis (GC-MS) with the identification of twentynine components demonstrating hexadecanoic acid (23.3\%) as the main constituent. Marengo et al. (2017), have reported the characterization of four Carduus species, namely (C. argyroa Biv., $C$. nutans subsp. macrocephalus (Desf.) Nyman, C. pycnocephalus, C. cephalanthus Viv) that grown in the region of the Mediterranean by phytochemical and biomolecular analyses. The current research aimed to investigate the chemical constitutes of the essential oils of the extracted $C$. pycnocephalus by Gas Chromatography-Mass Spectroscopic analysis (GC-MS), and to utilize the extracted sample to explore its biological aptitude as cytotoxic, and antimicrobial potency, as well as, the antioxidant characters of the extracted plant parts.

\section{Materials And Methods}

\section{Plant material and extraction process}

The plant materials of $C$. pycnocephalus were collected from the sandy habitat near Gamasa City, northern Mediterranean coast, Egypt $\left(31^{\circ} 30^{\prime} 22.24^{\prime \prime} \mathrm{N} 31^{\circ} 22^{\prime} 4.70^{\prime \prime} \mathrm{E}\right)$. The plant materials were cleaned and divided into small pieces. A weighed $20 \mathrm{gm}$ of the previously prepared plant materials were placed in a conical flask (250 $\mathrm{mL}$ ) contained $150 \mathrm{~mL}$ methanol and extracted by a shaker after two hours at room temperature. The extract was concentrated to a fixed volume after the complete extraction process. The produced methanol extract was filtered using qualitative Whatman filter paper no. 1 ( $125 \mathrm{~mm}$, Cat No 1001125 , Germany) and stored at $4{ }^{\circ} \mathrm{C}$ (Abd-ElGawad et al. 2020; Souza et al. 2018).

\section{Gas Chromatography-mass Spectroscopy (Gc-ms) Analysis}

The chemical constitutes of the plant were characterized by implementing the plant extract on Trace GC-TSQ mass spectrometer (Thermo Scientific, Austin, TX, USA) with a direct capillary column TG-5MS (30 m x 0.25 $\mathrm{mm} \times 0.25 \mu \mathrm{m}$ film thickness). The temperature of the column oven was firstly held at $50^{\circ} \mathrm{C}$, raised subsequently by a rate of $5^{\circ} \mathrm{C}$ per minute to reach $250^{\circ} \mathrm{C}$, and hold for $2 \mathrm{~min}$, and then the temperature was raised to the final temperature $\left(300^{\circ} \mathrm{C}\right)$ by $30^{\circ} \mathrm{C}$ per minute and hold for $2 \mathrm{~min}$. the injector and MS transfer line temperature were kept at 270 , and $260^{\circ} \mathrm{C}$, respectively. Helium $(\mathrm{He})$ was used as a carrier inert gas at a constant flow rate of $1 \mathrm{~mL} / \mathrm{min}$. The solvent was released after $4 \mathrm{~min}$ and the diluted samples of $1 \mu \mathrm{l}$ were injected directly using Autosampler AS1300 coupled with GC in the split mode. El mass spectroscopy was collected at $70 \mathrm{EV}$ ionization voltage over a range of $50-500$ for $\mathrm{m} / \mathrm{z}$ in packed scan mode. The temperature of the ion source was fixed at $200^{\circ} \mathrm{C}$. The chemical components of the individual extracted plant materials were 
interpreted by a comparison of their mass spectral data with those of WILEY 09, and NIST 14 mass spectroscopic database.

\section{Reagents}

1,1-Diphenyl-2-picrylhydrazyl (DPPH'), ascorbic acid, (3-(4,5-dimethylthiazol-2-yl)-2,5-diphenyltetrazolium bromide) (MTT), RPMI-1640 medium, and DMSO were purchased from Sigma Aldrich (St. Louis, USA). Fetal bovine serum (FBS; Gibco Life Technologies, Paisley, UK). Cephradin, Tetracycline, Azithromycin, and Ampicillin "antibiotics" were purchased from Merck (Darmstadt, Germany). Nutrient Agar (Contained Peptone, HM Peptone B \#, Yeast extract, Sodium chloride, Agar, and Beef extract) were purchased from Himedia Laboratories Pvt. Ltd. LBS Marg, Mumbai-400086, India.

\section{Instruments}

The horizontal water bath shaker (Memmert WB14, Schwabach, Germany), for the plant extraction process. GCTSQ mass spectrometer (Thermo Scientific, Austin, TX, USA), and UV/Vis spectrophotometer apparatus for colorimetric measurements (Spekol 11 spectrophotometer, analytic Jena AG, Jena, Germany). For antimicrobial tests: Laminar (HPH12, 1/PE AC, 50 Hz, 1P20, SN. 40328380) (Heraeus, Kendro, Langenselbold, Germany), and Incubator (Type: FRIOCELL 111, Medcenter Einrichtungen GmbH, D-82166, Grafelfing, Germany).

\section{Potential Biological Characteristics}

\section{Antioxidant DPPH assay}

The extracts of root, stem, leaves, and flower of $C$. pycnocephalus plant were in vitro screened as antioxidant agents by a colorimetric DPPH free radical assay. The method depended on measuring the intensity in the violet color of the DPPH solution. The assay was applied exactly as applied by the procedure reported by Kitts et al. (2000). In this course, different concentrations of each sample were prepared in serial dilutions (5-50 $\mathrm{mg} / \mathrm{L}$ ) in six testing tubes by mixing with methanol. $0.135 \mathrm{mM}$ of $\mathrm{DPPH}^{\circ}$ solution was prepared and subsequently add to each tube of the serial dilution of the investigated samples of the plant species. The tubes were next incubated in dark at room temperature for approximately $30 \mathrm{~min}$. The intensity in the violet color was measured on Spectrophotometric apparatus at a maximum wavelength of $517 \mathrm{~nm}$. The linear regression analysis was applied to calculate the inhibitive concentrations of each tested sample by plotting the exponential curve (Parejo et al. 2000) expressing the concentrations of the investigated samples against the percent of the remaining $\mathrm{DPPH}^{\bullet}$ radical. The percent of inhibitions were calculated by applying equation (1):

$$
\begin{aligned}
& \text { \% Inhibition }=[(\text { A control }- \text { A sample }) / A \text { control }] \times 100 \quad \text { Eq. (1) } \\
& \text { (A control) expressed the absorbance of the control sample. }
\end{aligned}
$$

(A sample) expressed the absorbance of each sample concentration.

Procedure Of Anticancer Activity

Tumor cell lines 
HePG-2 (Hepatocellular carcinoma) was selected as a human tumor cell line was purchased from ATCC via a holding company for biological products and vaccines (VACSERA), Cairo, Egypt.

\section{Preparation of MTT solution}

The MTT solution was prepared by mixing a solution of MTT in water $(10 \mathrm{mg} / \mathrm{mL})$, ethanol $(20 \mathrm{mg} / \mathrm{mL})$, and buffered salt solutions and media $(5 \mathrm{mg} / \mathrm{mL})$. The mixture was mixed by vortex or sonication, then filtered, and stored at $-20^{\circ} \mathrm{C}$.

Protocol of MTT assay (Zhu et al. 2017)

The cytotoxic activity of the investigated sample $C$. pycnocephalus was evaluated by MTT (3-(4,5-dimethyl-2thiazolyl)-2,5-diphenyl-2H-tetrazolium bromide) colorimetric assay utilizing an altered process termed by Terblanche et al. (2017). For the determination of the $\mathrm{IC}_{50}$ of each particular drug, the adherent HepG2 cells were seeded onto 96-well plates at an initial density $\left(3 \times 10^{3}\right.$ cells/well suspended in $100 \mu \mathrm{L}$ of complete medium). The crude plant extracts were prepared and used to stimulate the cells using five concentrations $(31.3,62.5,125,500$, and $1000 \mu \mathrm{g} / \mathrm{mL})$ in culture media. The experimental techniques were performed in duplicates, then plates were incubated for 24 hours in a $5 \% \mathrm{CO}_{2}$ at $37{ }^{\circ} \mathrm{C}$ for settle down and adherence. Next, a serial dilution of each prepared concentration of the drug was applied onto the cells for 48 hours after adherence. The medium was removed by aspiration and a weighed MTT $(0.5 \mathrm{mg} / \mathrm{mL})$ was dissolved in a culture fresh medium and practically applied onto cells and the plates were incubated at $37^{\circ} \mathrm{C}$ and $5 \% \mathrm{CO}_{2}$ for 4 hours. Ultimately SDS $(100 \mu \mathrm{L})$ was added into each well. The Reduction at cell growth was measured at $\left(\lambda_{\max }=570 \mathrm{~nm}\right)\left(\right.$ BioTek, Elx800, US) and the results were expressed as a percentage of control. The IC $\mathrm{C}_{50}$ values of the drug, articulated the concentration that affects roughly $50 \%$ death of tumor cells, were estimated through a straight linear regression, type sigmoidal, analyzed using Origin 8.0® software (OriginLab Corporation). The $\mathrm{IC}_{50}$ values were calculated by the fit line i.e. $\mathrm{Y}=\mathrm{a} * \mathrm{X}+\mathrm{b}$, in which $\mathrm{IC}_{50}=(0.57-b) / \mathrm{a}$. The percentage of inhibition in cell growth was calculated from the following equation (Eq. 2), in which $A$ is the absorbance of each control, and the tested sample:

$$
\backslash \% \text { Inhibition }=\frac{\text { Acontrol }- \text { Asample }}{\text { Acontrol }} \times 100 \mathrm{Eq}(2)
$$

The relative cell viability percentage was subsequently calculated from the following equation (Eq. 3), in which A expressed the control, and sample absorbance at $\lambda_{\max }=570 \mathrm{~nm}$.

$$
\backslash \% \text { Cellviability }=\frac{\text { Atreatedsamples }- \text { Ablank }}{\text { Acontrol }- \text { Ablank }} \times 100 \mathrm{Eq}(3)
$$

\section{Assessment Of The Antibacterial Activity Microbial Tendency}

The antimicrobial aptitudes of $C$. pycnocephalus extract were estimated using the agar well diffusion assay (Magaldi et al. 2004; Valgas et al. 2007). Cephradin, Tetracycline, Azithromycin, and Ampicillin were used as 
standard antibiotics for comparison scales.

\section{Bacterial species}

The microbial species were purchased from the Cairo Microbiological Resources Centre (Cairo MIRCEN), Faculty of Agriculture, Ain Shams University. Gram-negative bacteria: Escherichia coli (ATCC 10536), Pseudomonas aeruginosa (ATCC 9027), Salmonella typhimurium (ATCC 25566), Staphylococcus epidermidis (ATCC 12228). Gram-positive bacteria: Bacillus cereus (EMCC number 1080), Staphylococcus aureus (ATCC 6538), Staphylococcus haemolyticus (ATCC 29970), Staphylococcus xylosus (NCCP 10937), and Klebsella pneumonius (ATCC 10031).

\section{Preparation of the culture media}

28.0 grams of the nutrient agar were placed in a $2 \mathrm{~L}$ conical flask and suspended in $1 \mathrm{~L}$ distilled water. The conical flask contents were heated to boiling point to a completely dissolved medium. The mixture was sterilized by autoclave at $15 \mathrm{lbs}$ pressure, $121^{\circ} \mathrm{C}$ for 15 minutes. The medium was left to cool to $45-50{ }^{\circ} \mathrm{C}$. The medium can be enriched with $5-10 \%$ blood or biological fluids. The mixture was well-shaken and poured sterile Petri plates.

\section{Microbial Susceptibility Testing}

The antimicrobial activity of the investigated plant extract was estimated by filter paper disc technique (Murray et al. 1995; Kim et al. 2019) using inoculums containing $10^{6}$ bacterial cells / $\mathrm{mL}$ to spread on nutrient agar plates. Sterilized filter paper discs (Whatman no.1, $6 \mathrm{~mm}$ in diameter) were saturated with the extracted sample and another set of filter paper discs were soaked in methanol and served as controls. The discs were placed on the surface of agar plates seeded with the test bacterial species. The plates were incubated at $37^{\circ} \mathrm{C}$. The inhibition zone diameters (mm) were measured after 18-24 hours (Sardari et al. 1998).

\section{Results And Discussion}

In this research, we aim to explore the reactive chemical components of the essential oil of the methanol extracted $C$. pycnocephalus that are considered as the major factors affected on the biological aptitudes such as antioxidant, cytotoxic, and antibacterial activities. Each type of biological character is affected by a significant class of compounds that control its biological behavior i.e. the phenolic contents are crucial for potent antioxidant characters.

\section{Gas-chromatography Mass Spectroscopy "gc-ms"}

The components of the essential oil of the extracted $C$. pycnocephalus were elucidated by GasChromatography Mass Spectroscopy "GC-MS" (c.f. Fig. 2 \& Table 1). The results revealed that the extract of $C$. pycnocephalus includes about mainly six characterized components. In general, 3,5-dihydroxy-6-methyl-2,3dihydro-4H-pyran-4-one located the major component with $57.43 \%$ composition which was identified after 9.11 min. Accordingly, other constitutes were characterized with high composition \% such as $(E)-4-((2-$ methoxyoctadec-4-en-1-yl)oxy)methyl)-2,2-dimethyl-1,3-dioxolane (11.53\%), methyl (E)-octadec-11-enoate (10.98\%), and ethyl iso-allocholate (11.89\%), which were identified after 4.92, 29.18, and 35.71 minutes. Additionally, 2-(hept-6-yn-1-yl)malonic acid (3.53\%), and methyl 11-((2R,3S)-3-pentyloxiran-2-yl)undecanoate 
(4.64\%) were recorded after 4.15, and 25.89 minutes of retention time. The compounds were classified under several types of naturally occurring components, in which the class of ester of fatty acid has the majority of these components. Therefore, the esters of fatty acids includes $(E)-4-(((2-m e t h o x y o c t a d e c-4-e n-1-$ yl)oxy)methyl)-2,2-dimethyl-1,3-dioxolane, methyl 11-((2R,3S)-3-pentyl-oxiran-2-yl)undecanoate, and methyl ( $E$ )octadec-11-enoate. Another class of compounds was identified as hydrocarbons including two components namely, 2-(hept-6-yn-1-yl)malonic acid, and 3,5-dihydroxy-6-methyl-2,3-dihydro-4H-pyran-4-one. Ethyl isoallocholate followed the steroid class was found with $11.89 \%$ of composition (c.f. Supplementary file).

Alternatively, Al-Shammari et al. (2012), have interpreted the chemical constitutes isolated from the essential oil of $C$. pycnocephalus L. that grown in Saudi Arabia as basically nineteen components. Thus, the interpreted GC/MS of the plant extract indicated tetradecanoic acid (2.74\%), hexadecanoic acid ethyl ester (4.81\%), hexadecanoic acid (39.62\%), phytol isomer (6.31\%), linolenic acid ethyl ester (4.84\%), 9,12-linoleic acid (19.46\%), 1,2-benzendicarboxylic acid iso-octyl ester (7.11\%), and heptacosane (2.34\%). Therefore, the major component of this plant was related to hexadecanoic acid (39.62\%), which followed the fatty acid class of compounds. On the other hand, the GC-MS spectroscopic analysis of $C$. pycnocephalus that grown in Iran revealed that the essential oil of this extract contains twenty-nine components such as hexadecanoic acid (23.3\%), dibutyl, 1,2-benzene dicarboxylate (8.2\%), 6,10,14-trimethyl-2-pentadecanone (7.4\%), 1-pentyl octylbenzene (3.7\%), and tetradecanoic acid (4.3\%). The major component was found to be hexadecanoic acid $(23.3 \%)$, which is related to the fatty acid class. The established components are terpenes with low composition percentages, fatty acids, and their esters, hydrocarbons, and alkylbenzenes.

Additionally, twenty components of the esters of fatty acids isolated from C. pycnocephalus that grown in Saudi Arabia including 1,2-benzene dicarboxylic acid, dimethyl ester (31.08\%), azelaic acid dimethyl ester (7.6\%), and palmitic acid methyl ester (20.08\%) as the major constitutes of this plant extract. Other researches have been reported the composition of the components of the volatile oils of $C$. pycnocephalus grown in Iran (Esmaeili et al. 2005), and the identification of the terpenes, and flavone glycoside of $C$. pycnocephalus (AlShammari et al. 2015). 
Table 1

The interpreted components of the essential oil of the extracted C. pycnocephalus.

\begin{tabular}{|c|c|c|c|c|c|c|}
\hline Entry & Chemical name & Classification & $\begin{array}{l}\text { Retention } \\
\text { time (RT, } \\
\text { min) }\end{array}$ & $\begin{array}{l}\text { Molecular } \\
\text { Weight }\end{array}$ & $\begin{array}{l}\text { Molecular } \\
\text { formula }\end{array}$ & $\begin{array}{l}\text { Composition } \\
\%\end{array}$ \\
\hline 1 & $\begin{array}{l}2-(\text { Hept-6-yn-1-yl)malonic } \\
\text { acid }\end{array}$ & $\begin{array}{l}\text { Hydrocarbon } \\
\text { "dicarboxylic } \\
\text { acid" }\end{array}$ & 4.15 & 198.22 & $\mathrm{C}_{10} \mathrm{H}_{14} \mathrm{O}_{4}$ & 3.53 \\
\hline 2 & $\begin{array}{l}(E)-4-(((2- \\
\text { Methoxyoctadec-4-en-1- } \\
\text { yl)oxy)methyl)-2,2- } \\
\text { dimethyl-1,3-dioxolane }\end{array}$ & $\begin{array}{l}\text { Ester of fatty } \\
\text { acid }\end{array}$ & 4.92 & 412.66 & $\mathrm{C}_{25} \mathrm{H}_{48} \mathrm{O}_{4}$ & 11.53 \\
\hline 3 & $\begin{array}{l}\text { 3,5-Dihydroxy-6-methyl- } \\
\text { 2,3-dihydro-4H-pyran-4- } \\
\text { one }\end{array}$ & $\begin{array}{l}\text { Oxygenated } \\
\text { hydrocarbon }\end{array}$ & 9.11 & 144.13 & $\mathrm{C}_{6} \mathrm{H}_{8} \mathrm{O}_{4}$ & 57.43 \\
\hline 4 & $\begin{array}{l}\text { Methyl 11-((2R,3S)-3- } \\
\text { pentyloxiran-2- } \\
\text { yl)undecanoate }\end{array}$ & $\begin{array}{l}\text { Ester of fatty } \\
\text { acid }\end{array}$ & 25.89 & 312.49 & $\mathrm{C}_{19} \mathrm{H}_{36} \mathrm{O}_{3}$ & 4.64 \\
\hline 5 & $\begin{array}{l}\text { Methyl ( } E \text { )-octadec-11- } \\
\text { enoate }\end{array}$ & $\begin{array}{l}\text { Ester of fatty } \\
\text { acid }\end{array}$ & 29.18 & 296.50 & $\mathrm{C}_{19} \mathrm{H}_{36} \mathrm{O}_{2}$ & 10.98 \\
\hline \multirow[t]{2}{*}{6} & Ethyl iso-allocholate & Steroid & 35.71 & 436.63 & $\mathrm{C}_{26} \mathrm{H}_{44} \mathrm{O}_{5}$ & 11.89 \\
\hline & & & & & & $\triangle=100.0$ \\
\hline
\end{tabular}

\section{The Biological Characteristics Of The Plant Extracts}

Once upon a time, medicinal plant extracts have been applied in the treatment of various diseases, where the discovery of medicines lies in the presence of their active essential components in the contents of the plant extract, which led to an advance in pharmacology. The $C$. pycnocephalus plant has been widely used in traditional medicine for the treatment of many diseases.

\section{Antioxidant Activity - Dpph Assay}

As commonly reported, the antioxidant activities of $C$. pycnocephalus extracts were evaluated by DPPH $\left(2,2^{\prime}-\right.$ diphenyl-1-picrylhydrazyl radical) colorimetric assay as the most commonly used assay for the extracted plants. The procedure is usually applied for the hydrophilic antioxidant constitutes, while their application for evaluating the antioxidant capacity of the hydrophobic components is limited. In this method, the reactive components that provided potent radical scavenging activities should contribute with a weak $\mathrm{A}-\mathrm{H}$ bonding, which will increase the possibility for stabilizing or trapping the free radicals of DPPH at a maximum wavelength $517 \mathrm{~nm}$ resulting in a discoloration of the DPPH molecule. The violet color of the DPPH radical will change subsequently to colorless by increasing the concentration of the scrutinized samples. The importance of antioxidants arises from the ability of these components to inhibit the oxidation of lipids. The process followed by scavenging or trapping the free radicals of $\mathrm{DPPH}$, and hence determining the radical scavenging activity, as well as the assay in another route is an indication for reducing the capacity of the antioxidants in their reactions with DPPH radical. 
The inexpensive reagents applied to enable to run of the investigated sample by this proficient colorimetric assay (Blois 1958; Bondet et al. 1997; Brand-Williams et al. 1995). The mechanism of DPPH assay is postulated to underwent by a mean of a HAT (Litwinienko \& Ingold 2005), SET (Fotiet al. 2004; Huang et al. 2005), or mixed (Schaich et al. 2015) mechanisms as rendering to the succeeding reaction sequences:

DPPH·(violet) $+\mathrm{XOH} \rightarrow$ DPPHH (colorless) + XO'HAT Eq. (1)

$\mathrm{DPPH} \cdot($ violet $)+\mathrm{XOH} \rightarrow \mathrm{DPPH}$ (colorless) $+\mathrm{XO}+\mathrm{SET}$ Eq. (2)

The phytochemical constitutes (Kozyra et al. 2019) such as phenolic, and flavonoid contents are proficient components that act as strong scavengers for the DPPH radical increasing the antioxidant potential of these samples to protect the lipoperoxy, and lipid peroxidative from oxidation progression. The plausible mechanism of action was controlled by several beneficial effects. Thus, the presence of antioxidant agents enables the scavenging of the free radicals of DPPH depending on the nature of the source of the free radical components, and the concentration of the inspected sample. Therefore, by increasing the sample concentration, the percent of radical scavenging activity will increase resulting in a release in the color intensity of the DPPH (Siripatrawan \& Vitchayakitti 2016).

In this work, the antioxidant properties of root, stem, leaves, and flower extracts of $C$. pycnocephalus were in vitro evaluated by DPPH assay. The samples were tested for six diversified concentrations $(5,10,20,30,40$, and $50 \mathrm{mg} / \mathrm{L}$ ). The results in Table 2 verified that flower extract is the most potent antioxidant agent with $\mathrm{IC}_{50}=$ $30.69 \mathrm{mg} / \mathrm{L}$ relative to the results of ascorbic acid $\left(\mathrm{IC}_{50}=13.30 \mathrm{mg} / \mathrm{L}\right)$. The leaves extract of $C$. pycnocephalus located the second-order of radical scavenging capacity with $\mathrm{IC}_{50}=32.78 \mathrm{mg} / \mathrm{L}$, succeeding by the stem extract $\left(I C_{50}=41.31 \mathrm{mg} / \mathrm{L}\right)$, and root extract $\left(I_{50}=46.84 \mathrm{mg} / \mathrm{L}\right)$. Table 2 consistently also presented the radical scavenging activity (\%) of the extracted root, stem, leaves, and flower of $C$. pycnocephalus plant.

Figure 3 indicated the plotted percentages of radical scavenging activity against the various concentrations of each tested sample of $C$. pycnocephalus extract. A linear correlation between the scavenging activity $\%$ and their applicable concentrations $(5-50 \mathrm{mg} / \mathrm{L})$. The radical scavenging activity percent increased by increasing the sample concentration in a proportional relationship. Besides, the stem extract has the most potent scavenging activity for DPPH radicals at the lower concentration $(5 \mathrm{mg} / \mathrm{L})$ with $\%$ scavenging radical activity at $17.14 \pm 1.01 \%$, however, the root extract located the second-order of activity with \% scavenging radical activity at $12.58 \pm 0.74 \%$ at the same concentration. 
Table 2

The antioxidant results of the extracted root, stem, leaves, and flower of $C$. pycnocephalus plant.

\begin{tabular}{|c|c|c|c|c|c|c|}
\hline Sample & $\begin{array}{l}\text { Conc. } \\
\text { (mg/L) }\end{array}$ & $\mathrm{R}_{1}{ }^{[\mathrm{a}]}$ & $\mathrm{R}_{2}{ }^{[\mathrm{b}]}$ & $\begin{array}{l}\text { Mean } \\
\text { value }\end{array}$ & $\begin{array}{l}\text { Radical Scavenging Activity (\%) } \\
\text { [c] }\end{array}$ & $\begin{array}{l}\mathrm{IC}_{50}(\mathrm{mg} / \mathrm{L}) \\
\text { [d] }\end{array}$ \\
\hline \multirow[t]{6}{*}{ Root } & 5 & 0.644 & 0.662 & 0.653 & $12.58 \pm 0.74$ & \multirow[t]{6}{*}{46.84} \\
\hline & 10 & 0.553 & 0.531 & 0.542 & $27.44 \pm 1.61$ & \\
\hline & 20 & 0.508 & 0.53 & 0.519 & $30.52 \pm 1.80$ & \\
\hline & 30 & 0.457 & 0.475 & 0.466 & $37.62 \pm 2.21$ & \\
\hline & 40 & 0.415 & 0.41 & 0.4125 & $44.78 \pm 2.63$ & \\
\hline & 50 & 0.375 & 0.353 & 0.364 & $51.27 \pm 3.02$ & \\
\hline \multirow[t]{6}{*}{ Stem } & 5 & 0.623 & 0.615 & 0.619 & $17.14 \pm 1.01$ & \multirow[t]{6}{*}{41.31} \\
\hline & 10 & 0.575 & 0.564 & 0.5695 & $23.76 \pm 1.40$ & \\
\hline & 20 & 0.465 & 0.457 & 0.461 & $38.29 \pm 2.25$ & \\
\hline & 30 & 0.427 & 0.419 & 0.423 & $43.37 \pm 2.55$ & \\
\hline & 40 & 0.391 & 0.397 & 0.394 & $47.26 \pm 2.78$ & \\
\hline & 50 & 0.338 & 0.331 & 0.3345 & $55.22 \pm 3.25$ & \\
\hline \multirow[t]{6}{*}{ Leaves } & 5 & 0.666 & 0.673 & 0.6695 & $10.37 \pm 0.61$ & \multirow[t]{6}{*}{32.78} \\
\hline & 10 & 0.595 & 0.611 & 0.603 & $19.28 \pm 1.13$ & \\
\hline & 20 & 0.439 & 0.431 & 0.435 & $41.77 \pm 2.46$ & \\
\hline & 30 & 0.394 & 0.371 & 0.3825 & $48.80 \pm 2.87$ & \\
\hline & 40 & 0.341 & 0.337 & 0.339 & $54.62 \pm 3.21$ & \\
\hline & 50 & 0.213 & 0.208 & 0.2105 & $71.82 \pm 4.22$ & \\
\hline \multirow[t]{6}{*}{ Flower } & 5 & 0.676 & 0.688 & 0.682 & $8.70 \pm 0.51$ & \multirow[t]{6}{*}{30.69} \\
\hline & 10 & 0.579 & 0.591 & 0.585 & $21.69 \pm 1.28$ & \\
\hline & 20 & 0.411 & 0.401 & 0.406 & $45.65 \pm 2.69$ & \\
\hline & 30 & 0.324 & 0.327 & 0.3255 & $56.43 \pm 3.32$ & \\
\hline & 40 & 0.292 & 0.285 & 0.2885 & $61.38 \pm 3.61$ & \\
\hline & 50 & 0.233 & 0.238 & 0.2355 & $68.47 \pm 4.03$ & \\
\hline
\end{tabular}

[a], [b]: $R_{1}$, and $R_{2}$ referred to the values of the first and second read for the absorbance of the samples at different concentrations; [c]: RSA (\%) indicated the Radical Scavenging Activity (\%); [d]: $I \mathrm{I}_{50}$ referred to the inhibitive concentrations of the tested samples in $\mathrm{mg} / \mathrm{L}$. 
At the concentration of $10 \mathrm{mg} / \mathrm{L}$, the root extract was found with the most potent antioxidant activity $(\% \mathrm{RSA}=$ $27.44 \pm 1.61 \%)$, and the stem extract has the second-order of antioxidant capacity (\% RSA $=23.76 \pm 1.40 \%)$. The concentration of $20 \mathrm{mg} / \mathrm{L}$ of the investigated sample is more applicable for the comparison of the antioxidant scavenging radical activities for all the tested samples relative to the results of ascorbic acid. Thus, the flower extract revealed the potent antioxidant capacity of the other plant extracts with \% RSA at $45.65 \pm 2.69 \%$, this result is comparable with that of ascorbic acid (\% RSA $=64.97 \%)$. Leaves extract situated the second-order of antioxidant potency ( $\% \mathrm{RSA}=41.77 \pm 2.46 \%)$, then stem extract ( $\mathrm{RSA}=38.29 \pm 2.25 \%$ ), and finally the root extract (\% RSA $=30.52 \pm 1.80 \%$ ) at a concentration of $20 \mathrm{mg} / \mathrm{L}$. In the same sequence, flower extract is the most potent antioxidant agent at the concentrations of 30 , and $40 \mathrm{mg} / \mathrm{L}$ with $\%$ scavenging radical activity at $56.43 \pm 3.32$, and $61.38 \pm 3.61 \%$, respectively. The order of activity of the other plant constitutes is followed the extract of leaves (\% RSA $=48.80 \pm 2.87 \& 54.62 \pm 3.21 \%)$, stems (\% RSA $=43.37 \pm 2.55 \& 47.26 \pm 2.78 \%$ ), and to end with the root $(\% \mathrm{RSA}=37.62 \pm 2.21 \& 44.78 \pm 2.63 \%)$. Unexpectedly, at the higher concentration $(50 \mathrm{mg} / \mathrm{L})$, we noticed that leaves extract has the most potent antioxidant activity with \% scavenging radical activity at $71.82 \pm 4.22 \%$ than the flower extract with \% scavenging radical activity at $68.47 \pm 4.03 \%$. The behavior of stem and root extracts at the concentration of $50 \mathrm{mg} / \mathrm{L}$ followed the same sequence of the lower concentration (20, 30 , and $40 \mathrm{mg} / \mathrm{L}$ ) with \% scavenging radical activity at $55.22 \pm 3.25 \%$, and $51.27 \pm 3.02 \%$ (Table 2 ). The values of inhibitive concentrations " $\mathrm{IC}_{50}$ " is the half-maximal inhibitory concentration expressed the potential concentration of the tested sample that achieves scavenging for the radicals of DPPH by $50 \%$. The values of $\mathrm{IC}_{50}$ were calculated from the exponential curve (Parejo et al. 2000) plotting the sample concentrations against the remaining percent of $\mathrm{DPPH}^{\bullet}$ radical applying linear regression analysis.

The relationship between the $\mathrm{IC}_{50}$ values and the free radical scavenging activity percentages are inversely proportional. As specified from the results of $\mathrm{IC}_{50}$ values in Table 2, and Fig. 4, the flower extract is the most potent antioxidant agent with $I_{50}=30.69 \mathrm{mg} / \mathrm{L}$, relative to the $I_{50}$ value of ascorbic acid $\left(I C_{50}=13.30 \mathrm{mg} / \mathrm{L}\right)$. The order of antioxidant capacity of the other plant materials is found in the following order: leaves $\left(\mathrm{IC}_{50}=\right.$ $32.78 \mathrm{mg} / \mathrm{L})>\operatorname{stem}\left(\mathrm{IC}_{50}=41.31 \mathrm{mg} / \mathrm{L}\right)>\operatorname{root}\left(\mathrm{IC}_{50}=46.84 \mathrm{mg} / \mathrm{L}\right)$. The significant antioxidant potency of the samples depended in this scale of comparison on the nature of the chemical components contained in the distinct extract as the presence of electron sources such as reactive oxygen or nitrogen sorts (Tiwari et al. 2013; Singh et al. 2021) such as hydroxyl, phenoxyl, alkyl peroxyl, linoleic acid, peroxyl, and glutamyl radicals that can stabilize or trap the DPPH free radical improve the antioxidant aptitude (Kwak et al. 2009; Mishra 2016).

\section{Potential Antibacterial Activity}

The antibacterial activity of the extracted botanical ingredients of $C$. pycnocephalus from methanol was assessed by a disc diffusion technique as an in vitro antimicrobial susceptibility testing. The tested samples were prepared in a concentration of $10 \mathrm{mg} / \mathrm{L}$ from the root, stem, leaf, and flower extracts. The results are shown in Table 3, and Figure 5 revealed that the four samples are potent antibacterial agents against $E$. coli, $P$. aeruginosa, $S$. typhimurium, and $B$. cereus bacterial species. Particularly, potent antibacterial activities were recorded for leaf, and flower extracts against $E$. coli species with inhibition zones equivalent to that of antibiotic standards $(20 \mathrm{~mm})$. The root and stem extracts revealed remarkable antibacterial activities against $P$. aeruginosa species with inhibition zones 22 , and $20 \mathrm{~mm}$, respectively, with high potency than the antibiotic 
standard "Azithromycin" (13 mm), along with good activities of the leaf, and flower extracts with inhibition zones at $10 \mathrm{~mm}$.

By studying the results of the antibacterial activities of samples as inhibitors of bacterial growth, we found that the four samples had distinct activities in the process of inhibiting the growth of bacterial species of the type $S$. typhimurium by $14,13,26$, and $25 \mathrm{~mm}$, respectively, relative to the results of the antibiotic "Tetracycline" (10 $\mathrm{mm}$ ). Medium to high activities of the four samples was observed against $S$. epidermidis bacterial strains compared to the results of the four antibiotics, while the highest result of inhibiting the growth of those bacterial species was for the flower extract with an inhibition zone at $15 \mathrm{~mm}$. Looking at the results of the four samples as components of $C$. pycnocephalus, we found that the activity of methanolic extracts against Grampositive bacterial species is not good compared to their results with Gram-negative bacteria. This does not indicate the lack of quality of those extracts to inhibit the growth of Gram-positive bacteria, as some extracts have higher results than antibiotics such as extracts of leaves and flowers towards inhibiting the growth of bacterial species of type $B$. cereus by an amount of 23 and $25 \mathrm{~mm}$, respectively, and these results are higher than that obtained by all the antibiotics $(5-20 \mathrm{~mm})$ (Table 3$)$. 
Table 3

The antimicrobial activities are represented by the inhibition zone diameter $(\mathrm{mm})$ of the methanol extract of $C$. pycnocephalus and standard antibiotics.

\begin{tabular}{|c|c|c|c|c|c|c|c|c|}
\hline \multirow[t]{3}{*}{ Microbes } & \multicolumn{8}{|c|}{ Inhibition zone in $\mathrm{mm}$} \\
\hline & \multicolumn{4}{|c|}{ C. pycnocephalus $\left(10 \mathrm{mg} \mathrm{L}^{-1}\right)$} & \multicolumn{4}{|c|}{ Standard antibiotic $\left(10 \mathrm{mg} \mathrm{L}^{-1}\right)$} \\
\hline & Root & Stem & Leaf & Flower & Cephradin & Tetracycline & Azithromycin & Ampicillin \\
\hline & \multicolumn{8}{|c|}{ Gram-negative bacteria } \\
\hline E. coli & 13 & 10 & 20 & 20 & 15 & 20 & 20 & 20 \\
\hline$P$. aeruginosa & 22 & 20 & 10 & 10 & 0 & 0 & 13 & 0 \\
\hline $\begin{array}{l}\text { S. } \\
\text { typhimurium }\end{array}$ & 14 & 13 & 26 & 25 & 0 & 10 & 0 & 0 \\
\hline \multirow{2}{*}{$\begin{array}{l}\text { S. } \\
\text { epidermidis }\end{array}$} & 10 & 5 & 5 & 15 & 10 & 20 & 23 & 10 \\
\hline & \multicolumn{8}{|c|}{ Gram-positive bacteria } \\
\hline B. cereus & 11 & 13 & 23 & 25 & 20 & 10 & 20 & 5 \\
\hline S. aureus & 12 & 10 & 10 & 14 & 20 & 20 & 20 & 30 \\
\hline $\begin{array}{l}\text { S. } \\
\text { haemolyticus }\end{array}$ & 0 & 0 & 5 & 5 & 25 & 23 & 23 & 20 \\
\hline S. xylosus & 0 & 0 & 0 & 5 & 20 & 20 & 20 & 25 \\
\hline $\begin{array}{l}\text { K. } \\
\text { pneumonius }\end{array}$ & 10 & 10 & 13 & 13 & 10 & 20 & 13 & 5 \\
\hline $\mathrm{LSD}_{0.05}{ }^{[\mathrm{a}]}$ & 1.61 & 1.32 & 1.47 & 1.50 & 1.71 & 1.84 & 1.41 & 2.31 \\
\hline
\end{tabular}

${ }^{[a]} \mathrm{LSD}_{0.05}$ expressed the calculated least of the smallest significance between two means as each test was run on those two means (calculated by Factorial ANOVA).

Among the good results are also a high activity of inhibiting the growth of $S$. aureus of the flower methanolic extract by an amount of $14 \mathrm{~mm}$ and the good activity of leaf and flower extracts as inhibitors of $K$. pneumonius growth with an amount of $13 \mathrm{~mm}$ compared to the highest inhibitory activity of the antibiotic "Tetracycline" with an inhibition efficiency of $20 \mathrm{~mm}$. The results also demonstrated that the lowest efficiency to inhibit the growth of bacterial microorganisms was found against $S$. haemolyticus and S. xylosus using any of the four extracts with inhibition efficiency from inactive to $5 \mathrm{~mm}$ (Table 3 ).

The mechanism of action for the bacterial infections (Sawa, et al. 2019; Bascones-Martínez et al. 2009) is controlled by six main factors: (1) the interface with the bacterial cell wall (inhibit cell wall synthesis) (Mohammad et al. 2017), (2) depolarize the cell membrane (Higgins et al. 2005), (3) inhibition of the protein synthesis (De Vriese et al. 2006), (4) inhibition of nucleic acid synthesis (Srivastava et al. 2011), and (5) metabolic pathway inhibition (Li et al. 2019). Additionally, five basic mechanisms of action for antibiotics 
(Etebu \& Arikekpar 2016) are known including the inhibition of cell wall synthesis, protein synthesis (translation), nucleic acid synthesis, cell membranes alteration, and antimetabolite activity. The action of the tested samples as antibacterial agents is to continually disrupt and prevent the growth of bacterial species. The interpretation of these results is consistent with previous results in deducing the efficacy of the plant extract as an antimicrobial agent (El-Shahaby et al. 2013).

\section{Cytotoxic Activity}

The cytotoxic activity of $C$. pycnocephalus methanol extract was assessed using 3-(4,5-dimethylthiazolyl2)-2,5-diphenyltetrazolium bromide (MTT) colorimetric assay under distinct conditions. The method is identical to a cell number growth curve. The MTT reagent as a reliable indicator is so sensitive to the light, this engaged the run of the experiments in the dark. Hepatocellular carcinoma (HepG2) tumor cell line was selected to assess the anticancer potency of the investigated extracted medicinal plant. The method was applied for determining the cell metabolic activity based on the aptitude of nicotinamide adenine dinucleotide phosphate (NADPH)-dependent cellular oxidoreductase enzymes to reduce the MTT tetrazolium dye to its formazan "insoluble" that has a purple color. The number of viable cells should increase with growth, decrease with cytotoxic treatments, and remain the same (or plateau) with cytostatic treatments. $\mathrm{The} \mathrm{C}_{50}$ values expressed the concentration that represented $50 \%$ of the inhibition of cell growth was calculated by applying the curves obtained from plotted the percentages of cell survival versus drug concentration $(\mu \mathrm{M})$. Thus, the potency of cytotoxicity will rise by the decrease in the extract concentration and $\mathrm{IC}_{50}$ values. The MTT solution may be affected by the results of cytotoxicity, so we have run a control sample "blank" that was a few "empty" wells containing MTT solution without any of the cell lines. The control sample is a benefit for calculating the cell viability percent, as it produces $100 \%$ viability of healthy cells. The experiments were run using five concentrations of each plant extract $(31.3,62.5,125,500$, and $1000 \mu \mathrm{g} / \mathrm{mL}$ ) prepared in a serial dilution (Table 4).

Table 4

Cytotoxic results of the extracted $C$. pycnocephalus against HepG2 tumor cell line.

\begin{tabular}{|c|c|c|c|c|}
\hline Samples & Conc. $(\mu \mathrm{g} / \mathrm{mL})$ & $\mathrm{R}_{1}{ }^{\mathrm{la}]}$ & $\mathbf{R}_{2}{ }^{\text {[a] }}$ & $\mathrm{IC}_{50}(\mu \mathrm{g} / \mathrm{mL})^{[\mathrm{b}]}$ \\
\hline \multirow[t]{6}{*}{ C. pycnocephalus extract } & 1000 & 0.714 & 0.755 & \multirow[t]{6}{*}{46.2} \\
\hline & 500 & 1.4 & 1.32 & \\
\hline & 125 & 2.4 & 1.7 & \\
\hline & 62.5 & 1.6 & 1.7 & \\
\hline & 31.3 & 1.8 & 1.8 & \\
\hline & 0 & 1.3 & 1.3 & \\
\hline
\end{tabular}

${ }^{[a]} R_{1}, R_{2}$ are the absorbance read of the extracts at diverse concentrations.

[b] $\mathrm{IC}_{50}$ values are the inhibitive concentration expressed sample concentration that contributes roughly $50 \%$ of the death of cancer cells. 
Table 4 signified the results of the cytotoxic effects specified by the inhibitive concentration values of the extract of $C$. pycnocephalus on HepG2 tumor cell line. The results of cytotoxicity revealed that the extract of $C$. pycnocephalus has a potent cytotoxic effect on HePG-2 cell line with an $\mathrm{IC}_{50}$ value at $46.2 \mu \mathrm{g} / \mathrm{mL}$. It is worth mentioning that the mechanism of cytotoxicity of the extracted samples as cytotoxic agents on HepG2 tumor cell line is commonly dependent on the structural nature of the components of each extract, and the nature of the cancer cell line. Additionally, the nature of the particles of the extracted plants such as surface morphology, size, and aggregation of the particles might control the results of cytotoxicity. The efficiency of the plant extract as an efficient anti-cancer agent for tumor cell growth depended on several factors as previously noted, including the nature of the chemical components of this extract, the type of cancer cell, and the concentration of the extracted plant used in this assess (Khacha-Ananda et al. 2013).

$\mathrm{EC}_{50}$ of C. pycnocephalus extract

The dose-response relationship of the assessed $C$. pycnocephalus extract is plotted in Figure 6 . The doseresponse curve in Fig. 6a was normalized in the $\mathrm{X}$-axis direction by its $\mathrm{EC}_{50}$ value (Fig. $6 \mathrm{~b}$ ). The value of $\mathrm{EC}_{50}$ of the methanol extract of $C$. pycnocephalus was initially calculated by plotting the sample absorbance against the log of doses at different concentrations of the serial dilution (Fig. 6). The low concentrations of the extract are not enough to produce a response, while the high doses produce a maximal response, and the vertical point of the curve resembles an $\mathrm{EC}_{50}$ value. The data analysis specified that the higher concentration (dose $=1000$ $\mu \mathrm{g} / \mathrm{mL})$ as calculated for $\mathrm{EC}_{50}$ value $(2.82 \mu \mathrm{g} / \mathrm{mL})$ has a cytotoxic effect on HepG2 cell lines.

\section{Conclusion}

C. pycnocephalus plant is related to Asteraceae family displayed a wide spectrum of biological activities (Rustaiyan \& Faridchehr 2021; Conforti et al. 2008). In this work, we used the extract of $C$. pycnocephalus as a medicinal plant or any of its plant parts such as the stem, leaves, flowers, and roots to identify the chemical components that were isolated from the essential oils of the methanolic extract to study the effect of these components on the different biological results. We found that the four parts of the plant have high antioxidant capacities compared to the results of ascorbic acid as a result of these extracts containing a high percentage of phenolic components. Higher than antibiotics. Through that study, we discovered the efficiency of the plant extract as a cytotoxic agent with a moderate potency against the growth of hepatocellular carcinoma (HepG2), which indicated that the drug will not affect the growth of normal cells. The results also specified that the extracts of different parts of the plant, especially the that of leaves and flowers, have high and distinctive antibacterial activities to kill or inhibit the growth of the bacterial species such as E. coli, S. typhimurium, and $B$. cereus strains with higher efficiency than antibiotics.

\section{Declarations}

The authors declare no conflict of interest.

\section{References}


1. Al-Shammari LA, Hassan WHB, Al-Youssef HM (2012) Chemical composition and antimicrobial activity of the essential oil and lipid content of Carduus pycnocephalus L. growing in Saudi Arabia. J Chem Pharm Res 4(2):1281-1287

2. Al-Shammari LA, Hassan WHB, Al-Youssef HM (2015) Phytochemical and biological studies of Carduus pycnocephalus L. J Saudi Chem Soc 19(4):410-416. https://doi.org/10.1016/j.jscs.2012.05.002

3. Al-Shammari LA, Abdallah RH, Al-Youssef HM, Hassan WHB (2015) New pentacyclic triterpene ester and flavone glycoside from the biologically active extract of Carduus pycnocephalus L. J Pharmacogn Phytotherapy 7:45-55

4. Bascones-Martínez A, Muñoz-Corcuera M, Noronha S, Mota P, Bascones-llundain C, Campo-Trapero J (2009) Host defence mechanisms against bacterial aggression in periodontal disease: Basic mechanisms. Med Oral Patol Oral Cir Bucal 14:680-5

5. Blois M (1958) Antioxidant determinations by the use of a stable free radical. Nature 181:1199-1200

6. Bondet V, Brand-Williams W, Berset C (1997) Kinetics and mechanisms of antioxidant activity using the DPPH free radical method. LWT-Food Sci Technol 30(6):609-615

7. Boulos L (1983) Medicinal Plants of North Africa - Medicinal plants of the world 3. Reference Publications, Inc., 218 St. Clair River Drive, Box 344. Algonac, Michigan 48001, pp. 286

8. Brand-Williams W, Cuvelier ME, Berset C (1995) Use of a free radical method to evaluate antioxidant activity. LWT-Food Sci Technol 28(1):25-30

9. Brunetti G, Soler-Rovira P, Farrag K et al (2009) Tolerance and accumulation of heavy metals by wild plant species grown in contaminated soils in Apulia region, Southern Italy. Plant Soil 318:285-298. https://doi.org/10.1007/s11104-008-9838-3

10. Chaudhary SA (2000) Flora of the Kingdom of Saudi Arabia. Ministry of Agriculture and Water, National Herbarium, National Agriculture and Water Research Center, Riyadh, KSA, vol II, part 3, pp 117-202

11. Conforti F, loele G, Statti GA, Marrelli M, Ragno G, Menichini F (2008) Antiproliferative activity against human tumor cell lines and toxicity test on Mediterranean dietary plants. Food Chem Toxicol 46(10):3325-3332. https://doi.org/10.1016/j.fct.2008.08.004

12. de Briano AEE, Acciaresi HA, Briano JA (2013) Establishment, dispersal, and prevalence of Rhinocyllus conicus (Coleoptera: Curculionidae), a biological control agent of thistles, Carduus species (Asteraceae), in Argentina, with experimental information on its damage. Biol Control 67(2):186-193. https://doi.org/10.1016/j.biocontrol.2013.07.009

13. De Vriese AS, Van Coster R, Smet J, Seneca S, Lovering A, Van Haute LL et al (2006) Linezolid-induced inhibition of mitochondrial protein synthesis. Clin Infect Dis 42(8):1111-1117

14. Doing H, Biddiscombe EF, Knedlhans S (1969) Ecology and distribution of the carduus nutans group (nodding thistles) in Australia. Plant Ecol 17:313-351. https://doi.org/10.1007/BF01965915

15. El-Shahaby O, El-Zayat M, Salih E, El-Sherbiny IM, Reicha FM (2013) Evaluation of Antimicrobial Activity of Water Infusion Plant-Mediated Silver Nanoparticles. J Nanomed Nanotechnol 4:178. doi:10.4172/21577439.1000178

16. Abd-ElGawad AM, El-Amier YA, Assaeed AM, Al-Rowaily SL (2020) Interspecific variations in the habitats of Reichardia tingitana (L.) Roth leading to changes in its bioactive constituents and allelopathic activity. Saudi J Biol Sci 27:489-499. https://doi.org/10.1016/j.sjbs.2019.11.01 
17. Esmaeili A, Rustaiyan A, Nadimi M, Masoudi S, Tadayon F, Sedaghat S, Ebrahimpur N, Hajyzadeh E (2005) Volatile Constituents of Centaurea depressa M.B. and Carduus pycnocephalus L. Two Compositae Herbs Growing Wild in Iran. J Essent Oil Res 17(5):539-541. https://doi.org/10.1080/10412905.2005.9698988

18. Etebu E, Arikekpar I (2016) Antibiotics: Classification and mechanisms of action with emphasis on molecular perspectives. Int J Appl Microbiol Biotechnol Res 4:90-101

19. Foti MC, Daquino C, Geraci C (2004) Electron transfer reaction of cinnamic acids and their methyl esters with the DPPH(*) radical in alcoholic solutions. J Org Chem 69(7):2309-2314. doi.: 10.1021/jo035758q

20. Gallo MBC, Sarachine MJ (2009) Biological activities of lupeol. Int J Biomed Pharm Sci 3:46-66

21. Higgins DL, Chang R, Debabov DV, Leung J, Wu T, Krause KM, Sandvik E, Hubbard JM, Kaniga K, Schmidt DE Jr, Gao Q (2005) Telavancin, a multifunctional lipoglycopeptide, disrupts both cell wall synthesis and cell membrane integrity in methicillin-resistant Staphylococcus aureus. Antimicrob Agents Chemother 49(3):1127-1134

22. Huang D, Ou B, Prior RL (2005) The chemistry behind antioxidant capacity assay. J Agric Food Chem 53(6):1841-1856. doi.: 10.1021/jf030723c

23. Jaunatre R, Fonvieille N, Spiegelberger T et al (2016) Recovery of arbuscular mycorrhizal fungi root colonization after severe anthropogenic disturbance: Four species assessed in old-growth Mediterranean grassland. Folia Geobot 51:319-332. https://doi.org/10.1007/s12224-016-9254-z

24. Jordon-Thaden FE, Louda SM (2003) Chemistry of Cirsium and Carduus: a role in ecological risk assessment for biological control of weeds. Biochem Syst Ecol 31:1353-1396

25. Khacha-Ananda S, Tragoolpua K, Chantawannakul P, Tragoolpua Y (2013) Antioxidant and anti-cancer cell proliferation activity of propolis extracts from two extraction methods. Asian Pac J Cancer Prev 14(11):6991-6995

26. Kim E, Kim H-J, Yang S-M, Kim C-G, Choo D-W, Kim H-Y (2019) Rapid Identification of Staphylococcus Species Isolated from Food Samples by Matrix-Assisted Laser Desorption/Ionization Time-of-Flight Mass Spectrometry. J Microbiol Biotechnol 29:548-557. https://doi.org/10.4014/jmb.1901.01046

27. Kitts D, Wijewickreme A, Hu C (2000) Antioxidant properties of a North American ginseng extract. Mol Cell Biochem 203:1-10

28. Kozyra M, Komsta $Ł$, Wojtanowski K (2019) Analysis of phenolic compounds and antioxidant activity of methanolic extracts from inflorescences of Carduus sp. Phytochem Lett 31:256-262. https://doi.org/10.1016/j.phytol.2019.04.012

29. Kwak SY, Seo HS, Lee YS (2009) Synergistic antioxidative activities of hydroxycinnamoyl-peptides. Journal of Peptide Science: an official publication of the European Peptide Society 15(10):634-641

30. Li Y, Jia A, Wang Y, Dong L, Wang Y, He Y et al (2019) Immune effects of glycolysis or oxidative phosphorylation metabolic pathway in protecting against bacterial infection. J Cell Physiol 234(11):20298-20309

31. Litwinienko G, Ingold KU (2005) Abnormal solvent effects on hydrogen atom abstraction. 3. Novel kinetics in sequential proton loss electron transfer chemistry. J Org Chem 70(22):8982-8990. doi.: 10.1021/jo051477p

32. Magaldi S, Mata-Essayag S, de Capriles CH, Perez C, Colella MT, Olaizola C, Ontiveros Y (2004) Well diffusion for antifungal susceptibility testing. Int J Infect Dis 8(1):39-45. doi: 10.1016/j.ijid.2003.03.002 
33. Marengo A, Maxia A, Sanna C, Bertea CM, Bicchi C, Ballero M, Cagliero C, Rubiolo P (2017) Characterization of four wild edible Carduus species from the Mediterranean region via phytochemical and biomolecular analyses. Food Res Int 100(Part 1):822-831. https://doi.org/10.1016/j.foodres.2017.07.071

34. Mishra SS (2016) Detection and Analysis of Spin Trapped Radical Adducts by Using a-Phenyl-tert-Butyl Nitrone (PBN) Derivatives and GC/MS. University of Salford (United Kingdom)

35. Mohammad H, Younis W, Chen L, Peters CE, Pogliano J, Pogliano K et al (2017) Phenylthiazole antibacterial agents targeting cell wall synthesis exhibit potent activity in vitro and in vivo against vancomycin-resistant Enterococci. J Med Chem 60(6):2425-2438

36. Murray PR, Baroon EJ, Pfaller MA, Tenover FC, Yolke RH (1995) Manual of Clinical Microbiology, 6th edn. American Society for Microbiology, Washington DC, p 1482

37. Olivieri I (1985) Comparative electrophoretic studies of Carduus pycnocephalus L., c. tenuiflorus curt. (asteraceae), and their hybrids. Am J Bot 72(5):715-718. https://doi.org/10.1002/j.15372197.1985.tb08330.x

38. Olivieri I, Swan M, Gouyon PH (1983) Reproductive system and colonizing strategy of two species of Carduus (compositae). Oecologia 60:114-117. https://doi.org/10.1007/BF00379329

39. Orhan I, Orhan D, Ozcelik B (2009) Antiviral activity and cytotoxicity of the lipophilic extracts of various edible plants and their fatty acids. Food Chem 115:701

40. Parejo I, Codina C, Petrakis C, Kefalas P (2000) Evaluation of scavenging activity assessed by Co(II)/EDTAinduced luminol chemiluminescence and DPPH (2,2-diphenyl-1-picrylhydrazyl) free radical assay. J Pharmacol Toxicol Methods 44:507-512

41. Rustaiyan A, Faridchehr A (2021) Constituents and biological activities of selected genera of the Iranian Asteraceae family. J Herb Med 25:100405. https://doi.org/10.1016/j.hermed.2020.100405

42. Sardari S, Amin G, Micetich RG, Daneshtalab M (1998) Phytopharmaceuticals. Part 1: Antifungal activity of selected Iranian and Canadian plants. Pharm Biol 36(3):180-188

43. Sawa T, Kinoshita M, Inoue K, Ohara J, Moriyama K (2019) Immunoglobulin for treating bacterial infections: One more mechanism of action. Antibodies 8(4):52

44. Schaich KM, Tian X, Xie J (2015) Reprint of "Hurdles and pitfalls in measuring antioxidant efficacy: A critical evaluation of ABTS, DPPH, and ORAC assays". J Funct Foods 18(Part B) 782-796. https://doi.org/10.1016/j.jff.2015.05.024

45. Singh AK, Kumar S, Sinha T (2021) Antioxidants in Plant-Microbe Interaction. Antioxidants in PlantMicrobe Interaction. Springer, Singapore, pp 3-20

46. Siripatrawan U, Vitchayakitti W (2016) Improving functional properties of chitosan films as active food packaging by incorporating with propolis. Food Hydrocolloids 61:695-702

47. Souza MM, Silva BD, Costa CS, Badiale-Furlong E (2018) Free phenolic compounds extraction from Brazilian halophytes, soybean and rice bran by ultrasound-assisted and orbital shaker methods. An Acad Bras Cienc 90:3363-3372

48. Srivastava A, Talaue M, Liu S, Degen D, Ebright RY, Sineva E et al (2011) New target for inhibition of bacterial RNA polymerase: "switch region". Curr Opin Microbiol 14(5):532-543 
49. Terblanche U, SSemakalu CC, Mtunzi F, Pillay M (2017) Screening of variables influencing extraction yield of cotyledon orbiculata: $2^{3}$ full factorial design. Int J Pharmacogn Phytochem Res 9:303-312

50. Tiwari BK, Brunton NP, Brennan C (eds) (2013) Handbook of plant food phytochemicals: sources, stability and extraction. John Wiley \& Sons

51. Valgas C, de Souza SM, Smânia EFA, Smânia A Jr (2007) Screening methods to determine antibacterial activity of natural products. Braz J Microbiol 38:369-380. https://doi.org/10.1590/S151783822007000200034

52. Zhu Q, Jiang L, Wang X (2017) The expression of Duffy antigen receptor for chemokines by epithelial ovarian cancer decreases growth potential. Oncol Lett 13(6):4302-4306. doi: 10.3892/ol.2017.5954

\section{Figures}

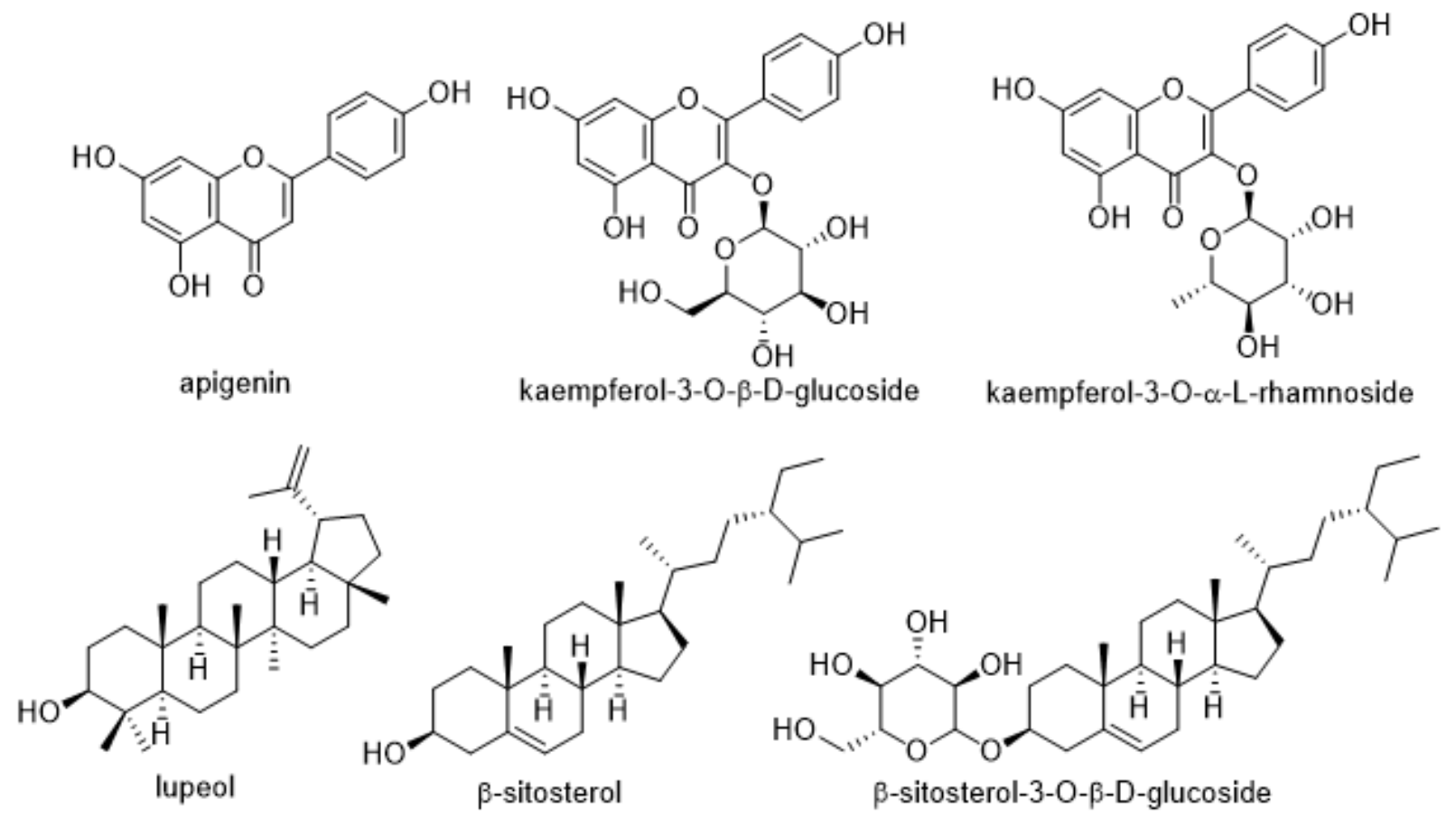

Figure 1

The effective chemical constitutes that were isolated from C. pycnocephalus. 
RT: $0000-37.45$ SUt 156

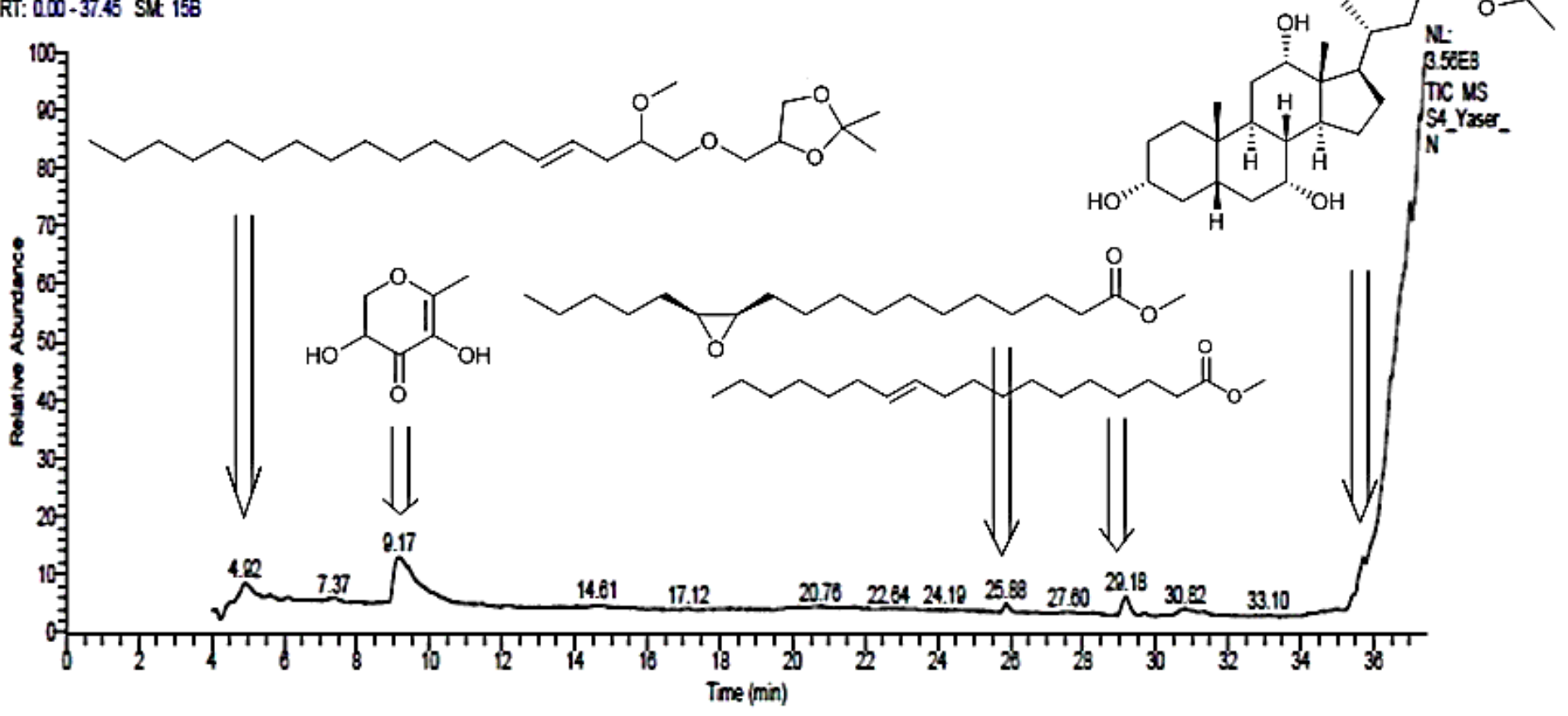

Figure 2

Chromatogram and structures of basic components of the essential oil of the extracted C. pycnocephalus by GC-MS.
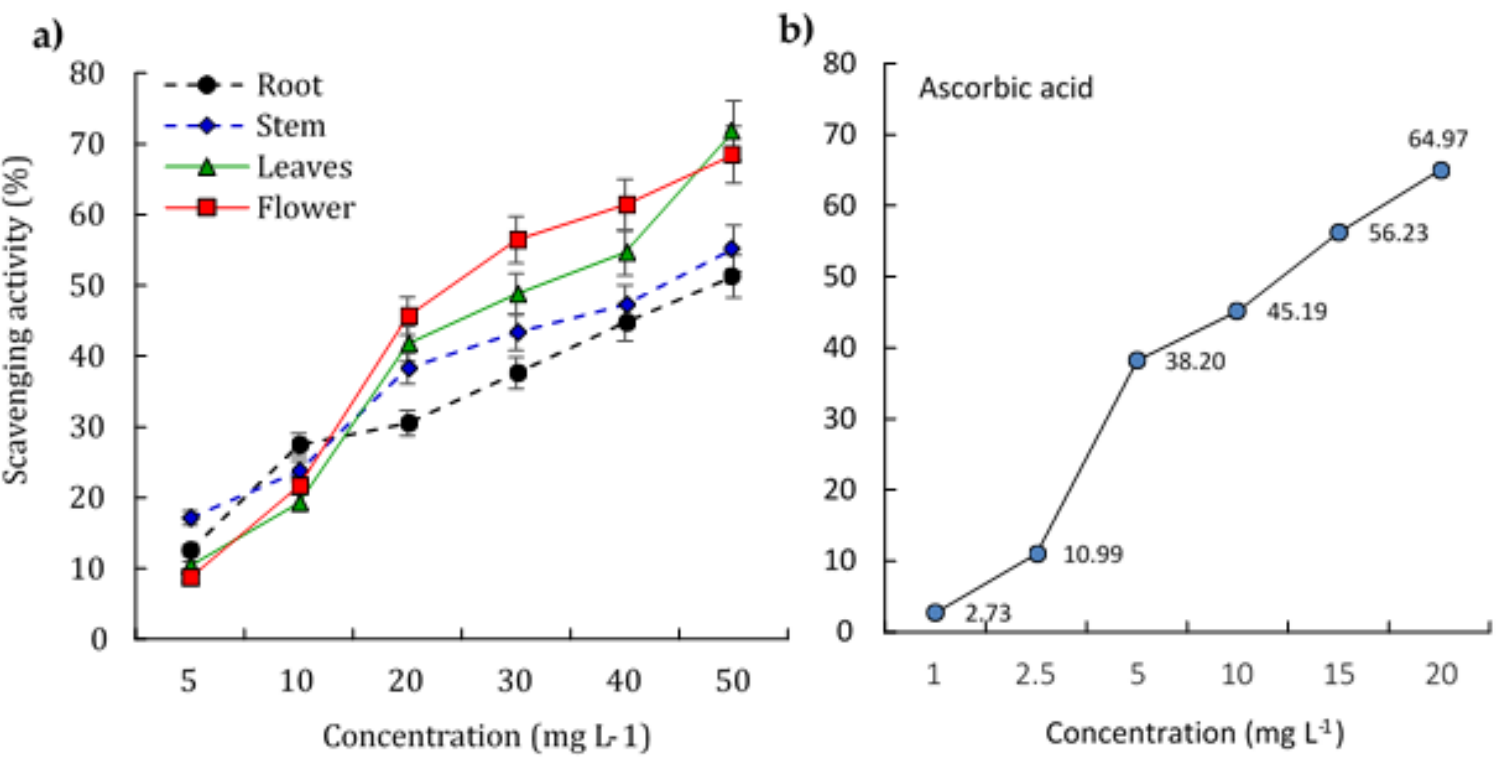

\section{Figure 3}

(a) Radical scavenging activity \% plotted against the various concentrations of each species of $\mathrm{C}$.

pycnocephalus extract. (b) The plotted radical scavenging activity \% against the various concentrations of ascorbic acid. 
$\square$ Root $\square$ Stem $\square$ Leaves $\square$ Flower

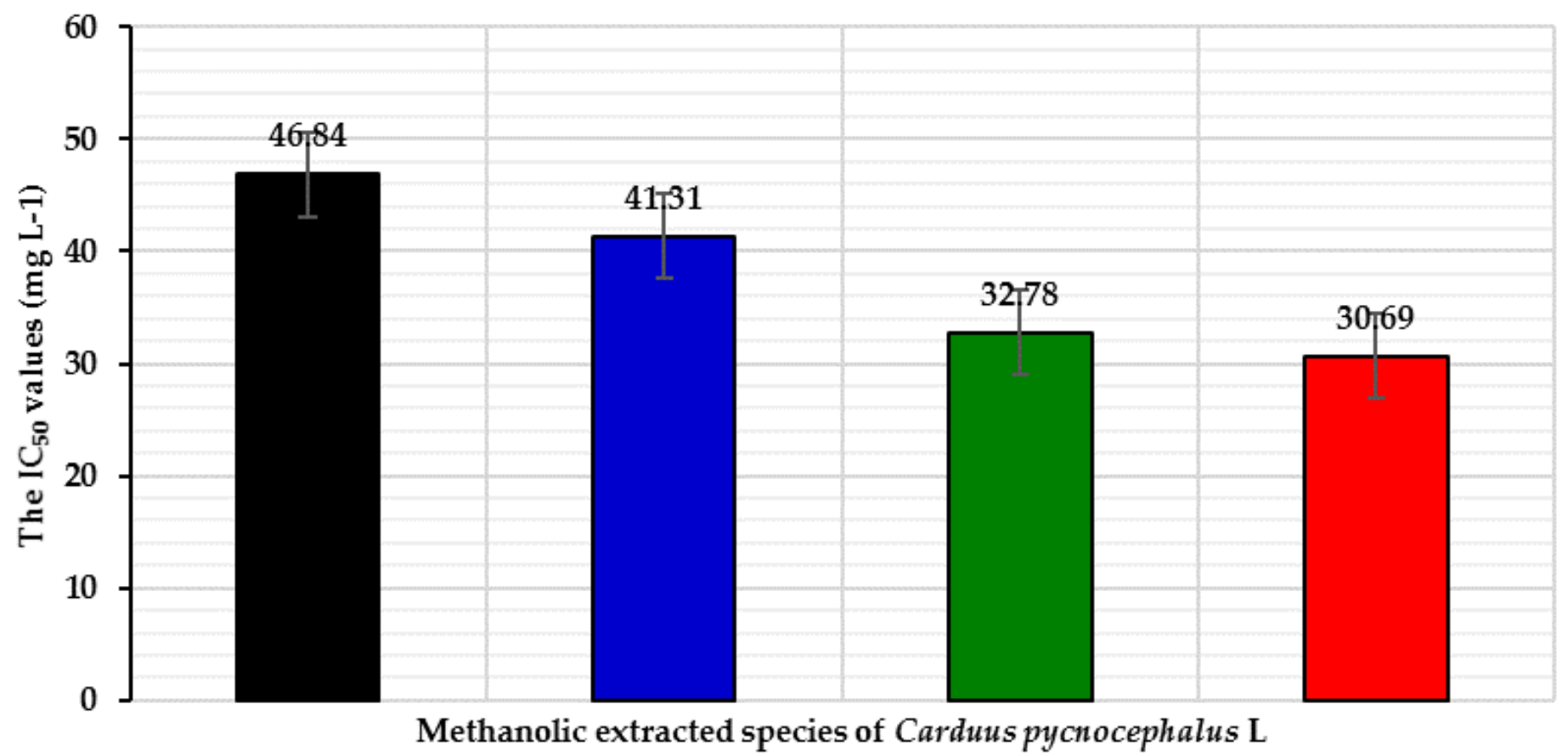

Figure 4

Comparison of the IC50 values of the investigated samples as antioxidant agents. 


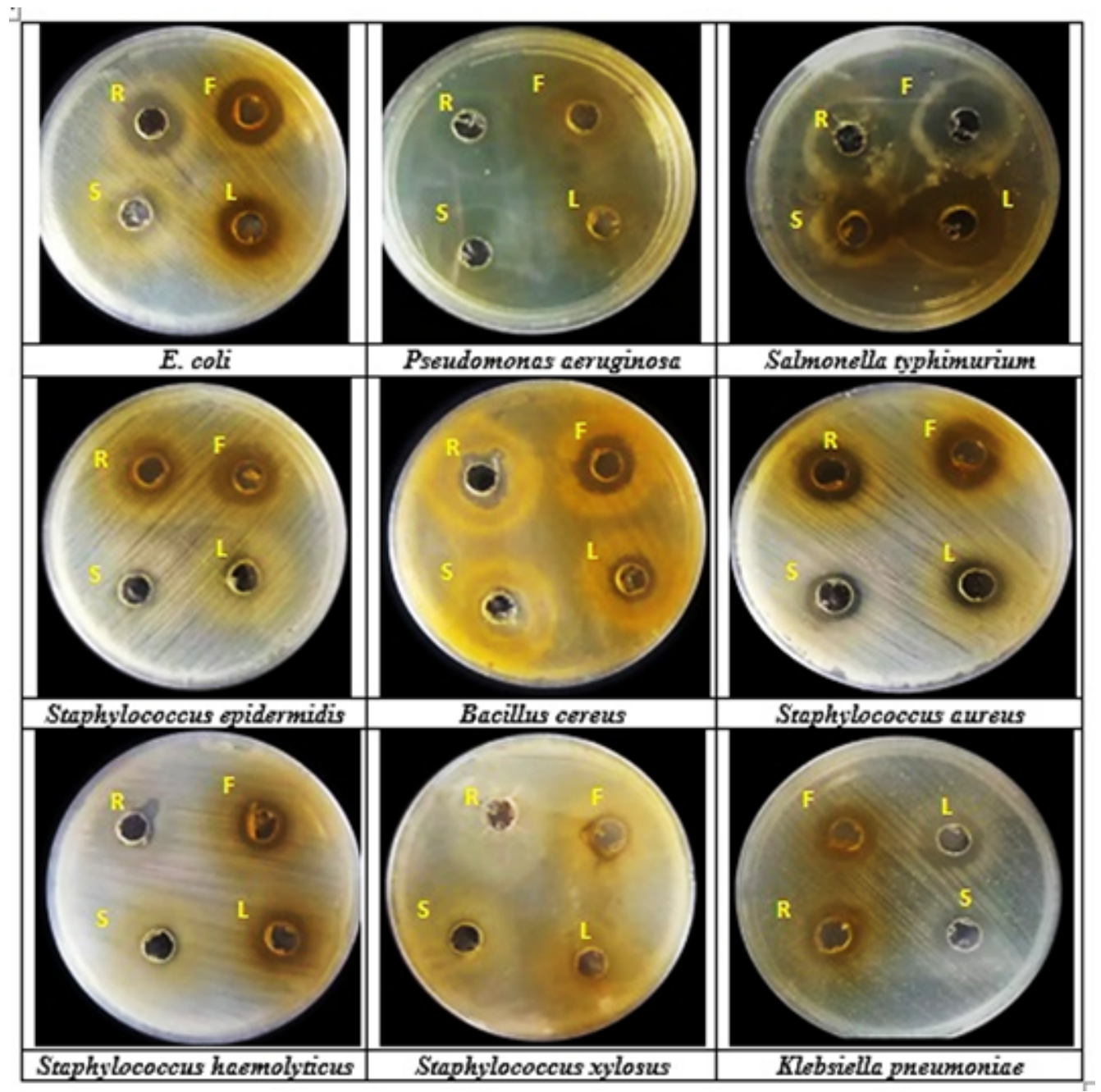

Figure 5

The inhibition zones were raised from the effects of the extracted root, stem, leaf, and flower of C.

pycnocephalus on the plates seeded with different bacterial species by disc diffusion technique. R $\equiv$ Root extract; $\mathrm{S} \equiv$ stem extract; $\mathrm{L} \equiv$ Leaf extract; $\mathrm{F} \equiv$ Flower extract.

a)

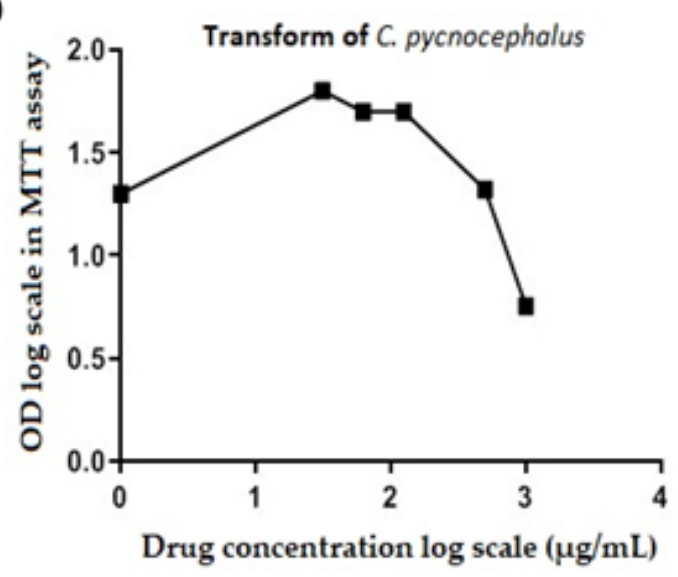

b)

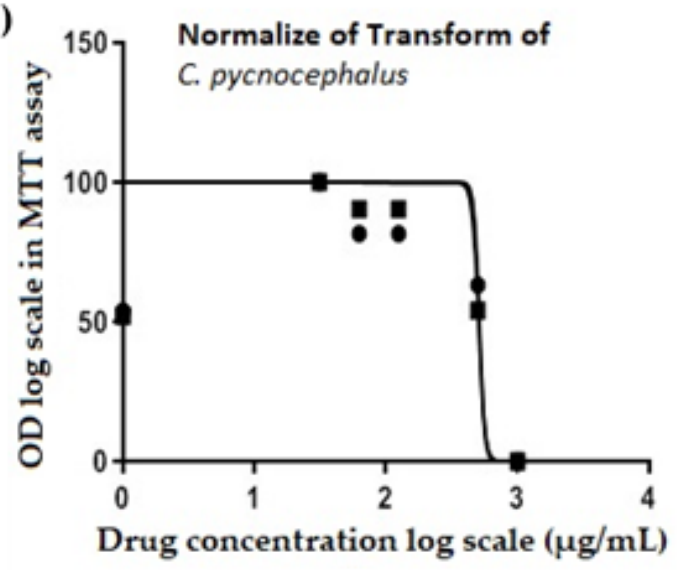

Figure 6 
Dose response curve. (a) Transform of C. pycnocephalus extract. (b) Normalization of transform of C. pycnocephalus extract. (OD) expressed the measured absorbance value at a definite concentration of the investigated extracted sample.

\section{Supplementary Files}

This is a list of supplementary files associated with this preprint. Click to download.

- GraphicalAbstract.docx

- SupplementaryData.docx 